\title{
JIDAL (DEBAT) SEBAGAI SALAH SATU METODE DAKWAH: MENIMBANG DALAM PERSPEKTIF HUKUM ISLAM
}

\author{
Muhammad Zulfunun \\ Program Studi Komunikasi Penyiaran Islam, Fakultas Agama Islam, Universitas Ibn Khaldun \\ Bogor, Indonesia \\ Email: Ibnuhasly@gmail.com
}

\begin{abstract}
Mujadalah or debate is an activity confronted each other face-proof. Sometimes sometimes leads to conflict. The problems that arise then comes to be a reason for prohibiting debate. Therefore it required the rule of law.This study uses literature refers to books, books and other related, The conclusion from this study is that the law muhajalah or debate is permissible.
\end{abstract}

Keywords: Mujadalah, Debate; Da'wah

\begin{abstract}
Abstrak
Mujadalah atau debat merupakan suatu kegitan saling menghadap-hadapkan hujjah. Yang kadang tak jarang menimbulkan pertentangan. Permasalahan-permasalahan yang muncul kemudian menjadi alas an untuk mengharamkan debat. Untuk itu diperlukan telaan sehingga didapatkan kepastian hukum. Penulisan ini menggunakan studi pustaka yang mengacu pada kitab, buku dan lainnya yang berkaitan. Kesimpulan yang didapat dari telaah ini ialah bahwa hukum muhajalah atau berdebat ialah mubah.
\end{abstract}

Kata Kunci: Mujadalah; Debat; Dakwah

\section{Pendahuluan}

Dalam berdakwah, para dai atau mubalig umumnya memanfaatkan kemampuan komunikasi yang dimilikinya. Dakwah bil-lisan seolah menjadi satu-satunya saluran yang mereka pergunakan dalam menyampaikan pesan-pesan Tuhan untuk dijadikan pegnan dalam kehidupan (Muhtadi, n.d).

Jidal (berdebat) dalam hal ini merupkan salah satu metode dalam menyampikan pesan-pesan ilahi kepada orag lain atupun khalayak yang memang sudah memilikikapasits keilmuan yang mumpuni, sehingga dapat diajak brtukar pikiran.

Dari sisi etimologi(bahasa), lafadz jidal diambil dari kata "jadala" yang berarti memintal, melilit. Apabila ditambah alif pada huruf jim yang mengikuti wazan $f a$ ala fungsinya untuk menunjukkan bersekutunya antara dua orang yakni menunjukkan saling berdebat, dan masdarnya adalah "mujadalah" yang berarti perdebatan. 
Dalam Lisanul 'Arob disebutkan: الجدل: مقا بلة الحجة بالحجة

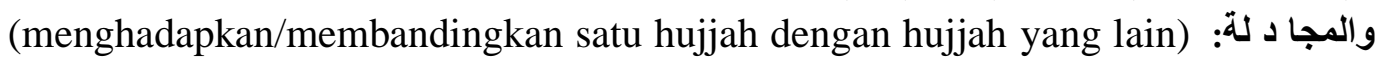
المنا ظرة وا لمخا صمة (perdebatan dan berbantah-bantahan)

Imam Gazali mengatakan mujadalah ialah: Setiap sanggahan terhadap pembicaraan orang lain dengan menampakkan ketimpangan di dalamnya, baik menyangkut lafadz, makna, atau maksud pembicara (Al-Ghazali, n.d).

Jadi, dari uraian di atas dapat disimpulkan bahwa jidal itu ialah: Upaya tukar pendapat yang dilakukan oleh dua pihak atau lebih yang bertujuan untuk mengalahkan pendapat lawan, sehingga menerima pendapat yang diajukan dengan cara mengungkapkan argumentasi dan bukti yang kuat.

\section{Jidal dalam Al-Qur'an}

Di dalam Al-Qur'an lafadz jidal disebutkan dengan beberapa arti, di antaranya:

a. Berbantah, seperti:

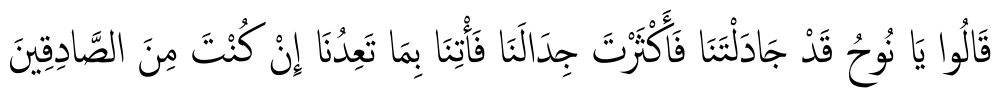

Artinya: mereka berkata: "Hai Nuh, Sesungguhnya kamu telah berbantah dengan Kami, dan kamu telah memperbanyak bantahanmu terhadap Kami, Maka datangkanlah kepada Kami azab yang kamu ancamkan kepada Kami, jika kamu Termasuk orang-orang yang benar" (Huud: 32)

b. Membantah, seperti:

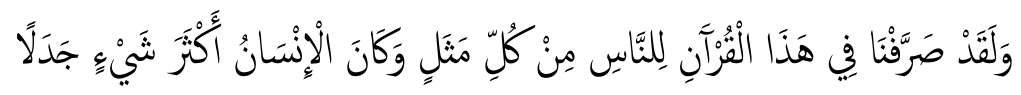

Artinya: "Dan sesungguhnya Kami telah mengulang-ulangi bagi manusia dalam Al Quran ini bermacam-macam perumpamaan. dan manusia adalah makhluk yang paling banyak membantah". (Al-Kahfi: 54)

c. Berdebat, seperti:

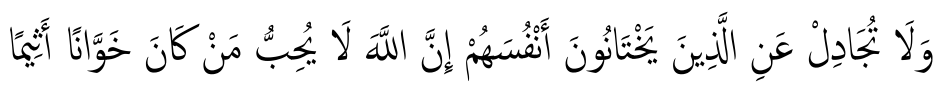

Artinya: "Dan janganlah kamu berdebat (untuk membela) orang-orang yang mengkhianati dirinya. Sesungguhnya Allah tidak menyukai orang-orang yang selalu berkhianat lagi bergelimang dosa”. (An-Nisa': 107)

\section{Bersoal jawab, seperti:}

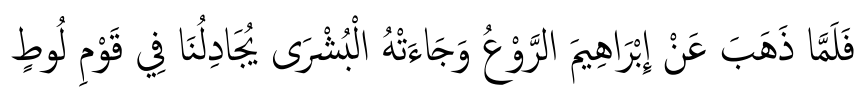

Artinya: "Maka tatkala rasa takut hilang dari Ibrahim dan berita gembira telah datang kepadanya, diapun bersoal jawab dengan (malaikat-malaikat) Kami tentang kaum Luth". (Huud: 74)

\section{Jidal Dalam Hadist}

Penyebutan jidal dalam hadist An-Nabawi di antaranya:

$$
\text { عن ابي هريرة عن النبي صلى الله عليه وسلم قال: المراء في القران كفر رواه ابو داود }
$$

Artinya: Dari Abu hurairah r.a, bahwasanya Nabi SAW bersabda: "Perdebatan tentang Al-Qur'an adalah kekufuran." 


\section{Hukum Jidal}

Tentang jidal ini ada 2(dua) Golongan, yakni: Golongan pertama, yang mengharamkan jidal secara muthlaq dan golongan kedua, yang membolehkan jidal.

\section{a. Alasan-Alasan Mereka yang Mengharamkan Jidal Secara Muthlaq}

\section{Firman Allah SWT:}

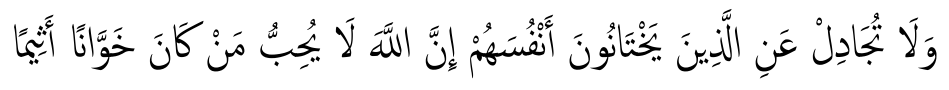

Artinya: "Dan janganlah kamu berdebat (untuk membela) orang-orang yang mengkhianati dirinya. Sesungguhnya Allah tidak menyukai orang-orang yang selalu berkhianat lagi bergelimang dosa". (An-Nisa':107)

lafadz "latujaadil" dalam ayat ini menunjukkan larangan berdebat.

\section{Firman Allah SWT:}

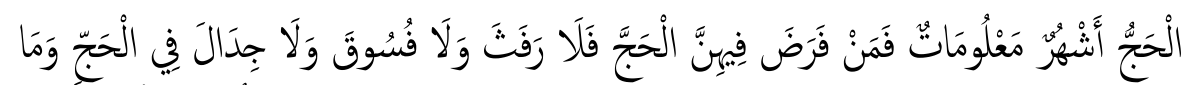

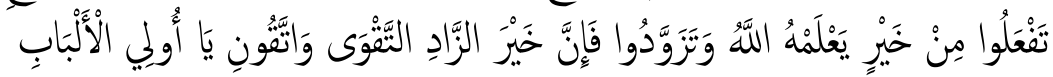

Artinya: "(Musim) haji adalah beberapa bulan yang dimaklumi Barangsiapa yang menetapkan niatnya dalam bulan itu akan mengerjakan haji, Maka tidak boleh rafats, berbuat Fasik dan berbantah-bantahan di dalam masa mengerjakan haji. dan apa yang kamu kerjakan berupa kebaikan, niscaya Allah mengetahuinya. Berbekallah, dan Sesungguhnya Sebaik-baik bekal adalah takwa dan bertakwalah kepada-Ku Hai orang-orang yang berakal".(Al-Baqarah: 197)

Ayat ini juga menunjukkan larangan berdebat, lafadz yang menunjukkan larangan tersebut ialah "walaa jidaala".

\section{Firman Allah SWT:}

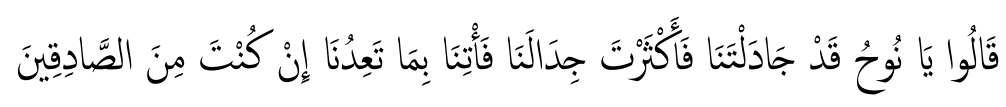

rtinya: "Mereka berkata: "Hai Nuh, Sesungguhnya kamu telah berbantah dengan Kami, dan kamu telah memperpanjang bantahanmu terhadap Kami, Maka datangkanlah kepada Kami azab yang kamu ancamkan kepada Kami, jika kamu Termasuk orang-orang yang benar". (Huud: 32)

\section{Firman Allah SWT:}

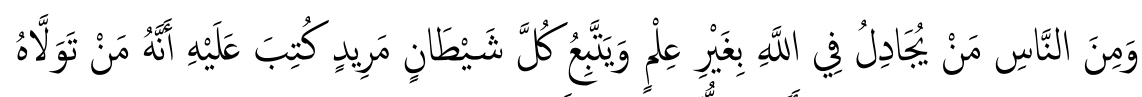

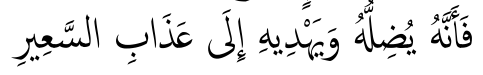

Artinya: "Dan di antara manusia ada orang yang membantah tentang Allah" tanpa ilmu pengetahuan dan mengikuti Setiap syaitan yang jahat, yang telah ditetapkan terhadap syaitan itu, bahwa Barangsiapa yang berkawan dengan Dia, tentu Dia akan menyesatkannya, dan membawanya ke azab neraka”. (Al-Hajj: 3-4)

\footnotetext{
1 Maksud membantah tentang Allah ialah membantah sifat-sifat dan kekuasaan Allah, misalnya dengan mengatakan bahwa malaikat-malaikat itu adalah puteri- puteri Allah dan Al Quran itu adalah dongengan orang- orang dahulu dan bahwa Allah tidak Kuasa menghidupkan orang-orang yang sudah mati dan telah menjadi tanah
} 
Ayat ini menjelaskan bahwa orang yang berdebat itu sebenarnya mengikuti syaitan, dia akan menyesatkannya dan membawa ke azab neraka.

\section{Hadist Nabi SAW:}

$$
\text { عن ابي هريرة عن النيي صلالله عليه وسلم قال: المراء في القرا ن كفر رواه ابو داود }
$$

Artinya: Dari Abu hurairah r.a, bahwasanya Nabi SAW bersabda: "Perdebatan tentang Al-Qur'an adalah kekufuran".

Hadist tersebut menjelaskan bahwa berdebat itu akan membawa kepada kekufuran

Dari dalil-dalil yang dikemukakan tentang larangan jidal, semuanya menggunakan lafadz yang muthlaq. Maka larangan itu pun harus difahami secara muthlaq juga, sebagaimana kaidah Ushul:

$$
\text { المطلق يبقي على إطلاقه }
$$

)Muthlaq itu tetap kepada kemuthlaqannya(

Sehingga dapat disimpulkan bahwa jidal itu haram dengan cara apapun.

\section{b. Alasan-Alasan yang Membolehkan Jidal}

Firman Allah SWT:

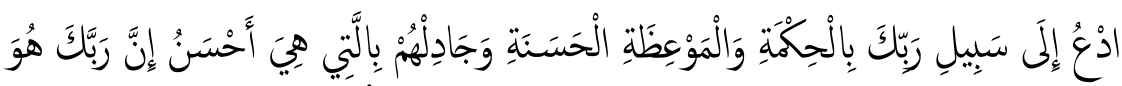

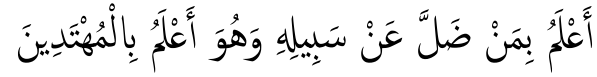

Artinya: "Serulah (manusia) kepada jalan Tuhan-mu dengan hikmah dan pelajaran yang baik dan bantahlah mereka dengan cara yang baik. Sesungguhnya Tuhanmu Dialah yang lebih mengetahui tentang siapa yang tersesat dari jalan-Nya dan Dialah yang lebih mengetahui orang-orang yang mendapat petunjuk". (An-Nahl: 125)

Firman Allah SWT:

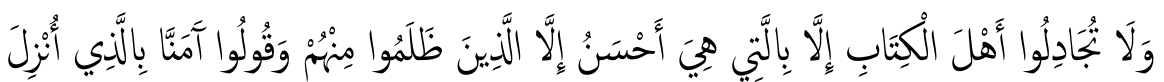

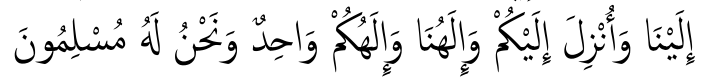

Artinya: "Dan janganlah kamu berdebat dengan Ahli Kitab, melainkan dengan cara yang paling baik, kecuali dengan orang-orang zalim di antara mereka, dan Katakanlah: "Kami telah beriman kepada (kitab-kitab) yang diturunkan kepada Kami dan yang diturunkan kepadamu; Tuhan Kami dan Tuhanmu adalah satu; dan Kami hanya kepada-Nya berserah diri". (Al-Ankabut: 46)

1. Adanya perintah jihad billisan

\section{Firman Allah SWT:}

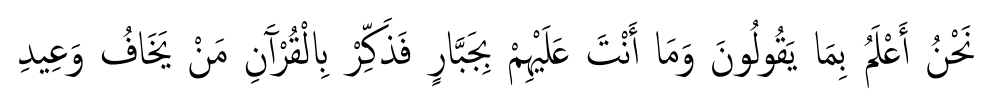

Artinya: "Kami lebih mengetahui tentang apa yang mereka katakan, dan kamu sekalikali bukanlah seorang pemaksa terhadap mereka. Maka berilah peringatan dengan Al Quran orang yang takut dengan ancaman-Ku.” (Al-Qaaf:45)

Sabda Rasulullah SAW: 


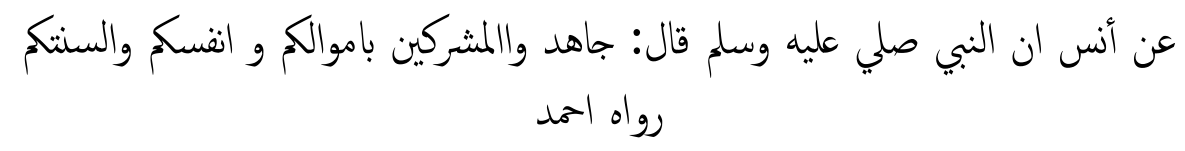

Artinya: Dari Annas r.a bahwasanya Nabi SAW bersabda: "Berjihadlah kamu terhadap orang-orang musyrik dengan harta ,jiwa, dan lisan kamu”. ( Hadist Riwayat Ahmad )

\section{c. Sanggahan Bagi yang Mengharamkan Jidal Secara Muthlaq}

Sebelum membahas alasan-alasan yang mengharamkan jidal secara muthlak, penulis ingin menjelaskan sedikit tentang mutlak dan muqayyad.

Muthlaq artinya yang terlepas, menurut istilah ialah: Suatu perkataan yang menunjukkan kepada sesuatu, dengan tidak ada ikatan syarat, sifat atau sesuatu ketentuan.

Perkataan "dollar" misalnya, ia menunjukkan sesuatu zat, yakni sejenis mata uang. Perkataan "dollar" ini muthlaq, karena ia mengandung arti/pengertian dollar Amerika, dollar Malaysia, dollar Singapura, dollar Australia dan sebagainya.

Kalau perkataan "dollar" tadi kita ikat dengan sifat lain, misalnya "dollar Australia", maka perkataan itu menjadi terikat. Satu perkataan yang terikat dengan sifat, syarat atau satu ketentuan, disebut "Muqayyad",yang menjadi pengikat dari kata-kata dollar di atas adalah perkataan "Australia", pengikat ini disebut "Qaid".

1. Dalil yang pertama, sebenarnya ayat ini berhubungan dengan ayat sebelumnya yaitu tentang pencurian yang dilakukan oleh salah seorang Sahabat (Tu'mah), dan ia menyembunyikan hasil curiannya di rumah salah seorang Yahudi, ia tidak mengakui perbuatannya malah menuduh Yahudi tersebut yang mencurinya. Hal ini oleh Sahabat yang lainnya dilaporkan kepada Nabi untuk membela Tu'mah walaupun mereka mengetahuinya, Kemudian turunlah ayat ini yang melarang Nabi untuk berdebat membela Sahabat tersebut, jadi ayat ini sebenarnaya tidak melarang jidal, tapi melarang membela kebatilan yang di antara caranya dengan jidal. Sehingga tidak bisa di jadikan alasan untuk mengharamkan jidal secara muthlaq.

2. Dalil kedua, perdebatan yang dimaksud dalam ayat ini adalah perdebatan yang tidak berguna atau dalam hal-hal yang telah di jelaskan Allah SWT kepada hamba-hamba-Nya dan menyebabkan kegaduhan, mudhorot kepada orang lain atau menyeru kepada kebatilan dan mengaburkan kebenaran, sedangkan perdebatan dengan cara yang baik untuk menjelaskan kebenaran sebagai kebenaran, dan kebatilan sebagai kebatilan jelas tidak termasuk dalam larangan ini.

3. Dalil ketiga, ayat ini hanya berisi khabaran, bukan larangan jidal. Kalaupun ayat ini berisi larangan tentang jidal, tetap tidak bisa dijadikan dasar untuk mengharamkan jidal, karena syari'at sebelum Nabi Muhammad itu tidak bisa dijadikan hujjah, kecuali yang dibenarkan oleh Nabi Muhammad, misalnya puasa Daud yang merupakan syari'at yang dibawa oleh Nabi Daud pada asalnya tidak boleh dikerjakan, tapi karena Nabi Muhammad memerintahkannya maka ia boleh dikerjakan. 
4. Dalil keempat, ayat ini hanya mengharamkan jidal tanpa ilmu pengetahuan, sehingga tidak menafikan jidal yang dilakukan dengan ilmu pengtahuan.Ini sesuai dengan firman Allah SWT yang artinya: "Maka janganlah kamu bertengkar tentang hal mereka, kecuali pertentangan yang nyata" (Q.S.AlKahfi:22). Abdurrahman As-Sa'di mengatakan: "Bertengkar" artinya berdebat, dan adu argumen. "Kecuali pertengkaran yang nyata" artinya yang didasarkan pada ilmu dan keyakinan yang pasti dan juga berguna. Sedangkan perdebatan yang didasarkan pada kebodohan dan dugaan buta semata atau sama sekali tidak berguna dan tidak ada manfaat transendental yang diperoleh dengan mengetahuinya. Seperti jumlah Ashabul Kahfi dan sebagainya. Maka terlalu banyak mendiskusikannya dan membahasnya secara serial hanya akan menyia-nyiakan waktu belaka dan memberikan dampak (negatif) terhadap rasa persahabatan di dalam hati tanpa ada faedah yang berarti. Jadi ayat ini sebenarnya adalah tidak mutlak, tapi terikat dengan kata-kata tanpa ilmu pengetahuan (Asy-Syalhub, n.d).

5. Dalil kelima, adapun larangan berdebat yang dimaksudkan dalam Hadist ini, disebutkan dalam kitab Aunul Ma'but jilid 12 halaman 353-354, ialah: Perdebatan yang timbul karena keraguan terhadap Al-Qur'an, apakah ia termasuk firman Allah SWT atau bukan, serta berdebat dalam rangka pengingkaran terhadap sebagian Al-Qur'an, ini jelas dilarang sebagaimana firman Allah SWT:

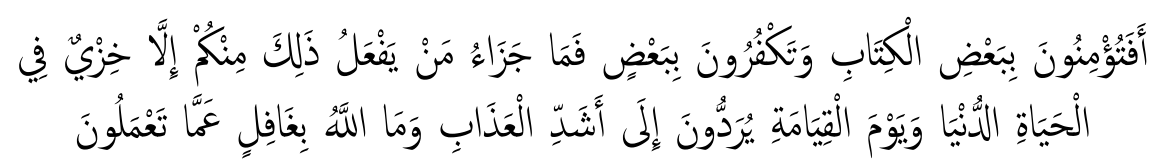

Artinya: “Apakah kamu beriman kepada sebahagian Al kitab dan ingkar terhadap sebahagian yang lain? Tiadalah Balasan bagi orang yang berbuat demikian daripadamu, melainkan kenistaan dalam kehidupan dunia, dan pada hari kiamat mereka dikembalikan kepada siksa yang sangat berat. Allah tidak lengah dari apa yang kamu perbuat." (Al-Baqarah: 85)

Dalil-dalil yang dikemukakan tentang haramnya jidal tidak disebutkan secara muthlaq tetapi dengan "qaid", sehingga haramnya jidal tersebut tidak boleh difahami secara muthlaq. Akan tetapi harus ditarik kepada yang muqayyad alias terbatas mengingat kasusnya sama, dan yang muthlaq diartikan menurut muqayyadnya. Sebagaimana kaidah Ushul:

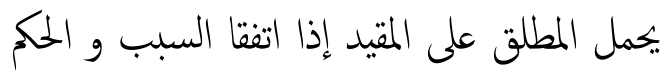

"Hendaklah dibawa yang muthlaq kepada yang muqayyad apabila keduanya sama sebab dan hukumnya."

Dari uraian di atas dapat disimpulkan bahwa alasan dari golongan pertama tidak bisa diterima.

\section{d. Penjelasan Tentang Dalil yang Membolehkan Jidal}

1. Dalil yang pertama, kata-kata "ud'u ilaa sabili rabbik" dalam ayat tersebut memerintahkan untuk mengajak manusia, sehingga (orang yang diajak) mengingkari thogut dan beriman kepada Allah SWT, serta mengeluarkan mereka dari kedzoliman menuju cahaya (Islam), dengan cara: 
a. Hikmah, maksudnya dengan dalil (burhan) atau hujjah yang jelas sehingga menunjukkan kebenaran dan menghilangkan kesamaran. Cara ini ditujukan kepada mereka yang ingin mengetahui hakikat kebenaran yang sesungguhnya, yakni mereka yang memiliki kemampuan berfikir yang tinggi atau sempurna, seperti para ulama', pemikir, dan cendikiawan.

b. Mau'izhah hasanah, (nasihat/peringatan yang baik),cara ini ditujukan kepada golongan awam, yakni orang yang belum dapat berfikir secara kritis dan mendalam, belum dapat menangkap pengertian yang tinggi-tinggi. Mereka diajak dengan anjuran dan didikan yang baik-baik, dengan ajaran yang mudah difahami.

c. Jidal billati hiya ahsan, maksudnya adalah jidal yang dilakukan dengan ilmu, bashirah, akhlak yang terpuji, kesantunan, keramahan, kelembutan, kata-kata yang baik, da'wah kepada kebenaran dan menjelaskan keindahannya, bantahan terhadap kebatilan dan menjelaskan keburukannya, dengan cara yang sederhana yang menyampaikan kepada yang dimaksud. Tujuannya bukanlah hanya sekedar cari menang kalah dan keinginan meninggikan diri pribadi. Namun tujuannya semata-mata menjelaskan kebenaran dan memberi petunjuk kepada makhluk. Adapun cara ini ditujukan kepada golongan yang cenderung menentang kebenaran dan cenderung untuk membantah dan berdebat.

Ibnu Katsir(Al qur'an al-Adzim;juz;3;hal:544) menyebutkan maksud jidal billati hiya ahsan:

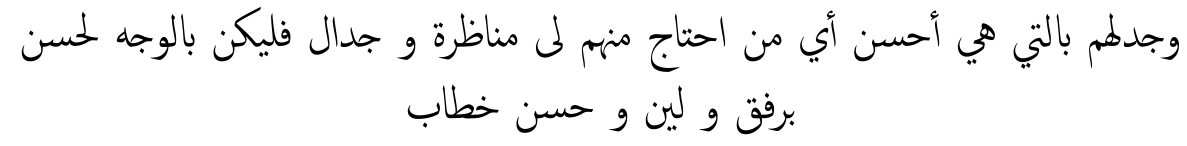

Dan yang dimaksud "wajadilhum billati hiya ahsan" ialah: dengan saling menyampaikan argumentasi dan debat itu harus dengan cara yang baik dengan penuh kelembutan dan perkataan yang baik.

Dari penjelasan di atas jelas sekali Allah memerintahkan untuk berda'wah, sehingga wajib kita melaksanakannya dengan metode (cara) yang telah dijelaskan, yang diantaranya adalah jidal. Kalau jidal itu haram maka tidak mungkin Allah memerintahkannya, ini menunjukkan bahwa jidal itu tidak haram.

2. Dalil kedua, ayat ini menjelaskan bolehnya berdebat kepada ahlul kitab dengan cara allati hiya ahsan, tetapi kepada Ahlul Kitab yang dzolim yaitu yang telah di berikan penjelasan dengan cara yang paling baik lalu mereka tetap membantah, maka kita boleh berdebat dengan mereka,dengan cara yang tidak ahsan, sebagaimana disebutkan oleh imam Syaukani dalam kitabnya Fathul Qadir jilid 4;hal:292, yaitu: dengan berlebih-lebihannya mereka dalam mujadalah dan mereka tidak memiliki adab terhadap orang muslim, maka boleh dengan keras atas mereka dan kasar dalam berdebat kapada mereka.

3. Alasan yang tiga, Jihad billisan ialah: Usaha yang sungguh-sungguh dengan memberikan penjelasan dan penjelasan dan keterangan terhadap segala bentuk penyelewengan agar kembali kepada Islam yang sejati. Adanya perintah ini menunjukkan bahwa jidal itu tidak haram. 
Setelah membahas dalil yang mengharamkan jidal secara muthlaq dan juga dalil yang membolehkan jidal, maka pendapat yang kuat adalah pendapat yang kedua dan dalil pendapat yang kedua sudah cukup untuk membantah alasan dari pendapat pertama. Sehingga dapat disimpulkan bahwa hukum jidal itu adalah mubah kecuali yang tidak dengan jalan "allati hiya ahsan", atau kepada Ahlul Kitab yang dzolim.

\section{e. Contoh Jidal Allati Hiya Ahsan Dalam Al-Qur'an}

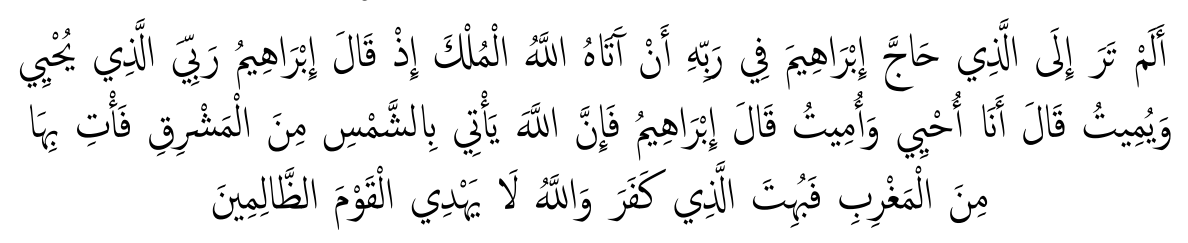

Artinya: “Apakah kamu tidak memperhatikan orang yang mendebat Ibrahim tentang Tuhannya (Allah) karena Allah telah memberikan kepada orang itu pemerintahan (kekuasaan). ketika Ibrahim mengatakan: "Tuhanku ialah yang menghidupkan dan mematikan," orang itu berkata: "Saya dapat menghidupkan dan mematikan". Ibrahim berkata: "Sesungguhnya Allah menerbitkan matahari dari timur, Maka terbitkanlah Dia dari barat," lalu terdiamlah orang kafir itu; dan Allah tidak memberi petunjuk kepada orang-orang yang dzalim." (Al-Baqarah: 258)

\section{Kesimpulan}

Setelah melakukan kajian secara beruntun berdasarkan Nash-nash, maka penulis menyimpulkan bahwa: Jidal hukumnya mubah, kecuali yang tidak dengan jalan allati hiya ahsan. Kedua, mubah hukumnya berdebat dengan cara yang tidak ahsan kepada orang kafir yang dzolim dan terakhir Jidal merupakan salah satu metode da'wah.

\section{Referensi}

Al-Qur'an dan Terjemahnya, 2005. PT. Syamil Cipta Media

Lisanul 'Arob, Abu Fadhl Jamaluddin Muhammad bin Makram, Ibnu Manzur Al-Afriqy AlAasry. 1300 H. Beirut Lebanon:Darul Fikr.

Petaka Lisan, Dr. Said bin Ali bin Wahf Al-Qahthany.1410 H. Solo: At-Tibyan.

Etika Berbicara, Fuad Abdul Aziz As-Syalhub.2009 M. Surabaya: El-Ba.

Intisari Ihya' Ulumuddin, Al-Ghazali.2006 M Jakarta Timur:Robbani Press.

Perkembangan Dakwah Pada Saat Ini, http://www.homeartikel.co.cc.2009 M

Kamus Al- Munawwir, 2007. Surabaya: Pustaka Progresif.

Aunul ma'but, Abu ath-Thayyib Muhammad Syamsul Haq Al-A’zim.

Muhtadi, A.S. (n.d)Komunikasi Dakwah teori pendekatan dan aplikasi, Bandung: Simbiosa Rakatama Media. 